\title{
Pancreatic Secretory Trypsin Inhibitor
}

National Cancer Institute

\section{Source}

National Cancer Institute. Pancreatic Secretory Trypsin Inhibitor. NCI Thesaurus. Code C17448.

Pancreatic secretory trypsin inhibitor (79 aa, $\sim 9 \mathrm{kDa}$ ) is encoded by the human SPINK1 gene. This protein plays a role in the modulation of trypsin activity. 